\title{
Pengembangan Modul Pendidikan dan Pelatihan Materi Perencanaan Perkerasan Jalan pada Perusahaan Jasa Konstruksi
}

\author{
Daniel Jesayanto Jaya, Nuryadin Eko Raharjo \\ Pendidikan Teknologi dan Kejuruan, Pascasarjana, Universitas Negeri Yogyakarta
}

\section{Edcomtech}

\section{Jurnal Kajian}

Teknologi Pendidikan

Volume 6, No 1, April 2021

162-172

Submitted 21-07-2020

Accepted 30-12-2020

Corresponding Author

Daniel Jesayanto Jaya

Dhutasoit43@gmail.com

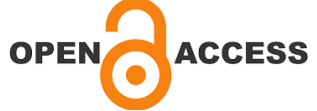

\begin{abstract}
Abstrak
Tujuan penelitian ini adalah melakukan pengembangan Modul Pendidikan dan Pelatihan Perencanaan Perkerasan Jalan yang layak digunakan menjadi panduan belajar di perusahaan jasa konstruksi selaku peserta diklat. Metode yang digunakan adalah penelitian dan pengembangan (Research and Development) dengan tahapan Define (Pendefinisian), Design (Perancangan), Develop (Pengembangan) dan Disseminate (Penyebaran). Teknik pengumpulan datanya menggunakan observasi, dokumentasi, dan angket. Uji validitas kelayakan modul dilakukan pada instrumen yang dituangkan dalam angket dengan teknik analisis data secara deskriptif. Dari hasil validasi. ahli materi menyatakan modul Perencanaan Perkerasan Jalan sudah memenuhi kriteria sangat layak karena sudah mencakup kompetensi yang dibutuhkan peserta diklat dengan jabatan pelaksana atau pengawas pekerjaan jalan, sementara validasi ahli media menyatakan modul sudah memenuhi kaidah media yang menarik, mudah diakses, dipahami sehingga sangat layak digunakan oleh peserta diklat Perencanaan Perkerasan Jalan.
\end{abstract}

Kata Kunci: Media Pembelajaran Modul, Materi Perencanaan Perkerasan Jalan, Research and Development 4D Thiagarajan

\begin{abstract}
The purpose of this research is to develop a Road Pavement Planning Education and Training Module that is suitable to be used as a learning guide in construction service companies as training participants.. The method used is research and development (Research and Development) with the stages of Define (Definition), Design (Designing), Develop (Development) and Disseminate (Spread). The data collection technique uses observation, documentation and questionnaires. The module feasibility validity test was carried out on the instruments outlined in the questionnaire with descriptive data analysis techniques. From the validation results. The material expert stated that the Road Pavement Planning module met the very feasible criteria because it included the competencies needed by training participants with the position of implementing or supervising road works, while the validation of the media expert stated that the module had met the rules of media that was attractive, easy to access, understood so it was very suitable for use by Road Pavement Planning training participants.
\end{abstract}

Keywords: Learning Media Module, Road Pavement Planning Materials, 4D Thiagarajan Research and Development 


\section{LATAR BELAKANG}

Pergerakan cepat ilmu pengetahuan yang saat ini berbasiskan teknologi merupakan tantangan besar bagi dunia pendidikan Indonesia yang dihadapkan dengan minimnya manusia dengan kemampuan yang berkualitas. Untuk memenuhi kebutuhan sumber daya manusia (SDM) yang mumpuni itu, harus diiringi dengan kemajuan dunia pendidikan secara umum. Sesuai perkembangan zaman, pendidikan di Indonesia mulai berbenah diri, salah satunya dunia pendidikan tinggi atau universitas yang harus melahirkan lulusan yang berkualitas dan dibutuhkan dunia kerja. Ditegaskan melalui Undang-undang Republik Indonesia No.12 Tahun 2012 tentang Pendidikan Tinggi Pasal 48 Ayat (1) yang menyatakan bahwa salah satu peran perguruan tinggi adalah aktif dalam berkolaborasi antara perguruan tinggi dengan dunia industri dan dunia usaha. Dalam penelitian ini melibatkan kerjasama antara Fakultas Teknik UNY dengan perusahaan jasa konstruksi.

Dalam Undang-Undang Republik Indonesia Nomor 13 Tahun 2003 tentang ketenagakerjaan, tenaga kerja merupakan individu yang dianggap mampu melaksanakan satu pekerjaan tertentu dalam memproduksi barang maupun jasa yang berguna memenuhi kebutuhan individu maupun kelompok. Hal ini diperkuat Peraturan Menteri Ketenagakerjaan No. 2/2016 mengenai Sistem Standardisasi Kompetensi Kerja Nasional menyatakan pelatihan kerja atau diklat adalah suatu kegiatan yang melatih, meningkatkan dan mengembangkan work competency, productivity, discipline, attitude, dan etika dalam bekerja pada keterampilan atau keahlian tertentu. Pendidikan dan pelatihan (diklat) adalah sebuah sistem yang bertujuan menghasilkan perubahan sikap dan tingkah laku manusia yang akan meningkatkan keterampilan dan kedewasaan personal (Daryanto \& Bintoro, 2014). Pelatihan di dunia kerja bisa dilakukan pada masa menjadi trainee atau sesudah ditempatkan pada bidang tertentu (Nawawi, 2016).

Perusahaan jasa konstruksi menyadari bahwasanya SDM yang dimiliki harus selalu dikembangkan agar tercipta manusia yang mumpuni dan sesuai dengan perkembangan kebutuhan industri konstruksi namun hal ini terhambat karena belum adanya panduan baku dalam diklat perusahaan yang juga mempersulit proses penilaian untuk kenaikan jabatan karyawan. Dalam pelaksanaan pelatihan diatur oleh Peraturan Menteri Ketenagakerjaan dan Transportasi No.8/2014 dimana Pelaksanaan Pelatihan Berbasis Kompetensi (PBK) Adalah proses interaksi antara peserta pelatihan dengan pelatih melalui berbagai metode dan teknik, serta pemanfaatan perangkat media pelatihan pendidikan yang sesuai dengan tujuan akhir pelatihan. Meskipun telah didukung berbagai aturan yang berlaku seringkali diklat tidak berjalan baik mulai dari kendala materi hingga kendala media pembelajaran

Sadiman, et al. (2011) menerangkan bahwa media pembelajaran yang dikembangkan secara tepat dan memiliki variasi menarik akan dapat mengatasi respon pasif peserta diklat, dan memunculkan kegairahan belajar serta menjadi alternatif dari macam-macam cara yang dapat diaplikasikan dalam pendidikan dan pelatihan SDM. Unsur penting yang mempengaruhi proses pembelajaran adalah penggunaan sumber belajar yang dapat digunakan saat pembelajaran konvensional maupun online atau non-konvensional. Penggunaan bahan ajar memungkinkan setiap peserta diklat dapat mempelajari materi secara berurutan tersistematika sehingga dapat mengaplikasikan suatu kompetensi yang diharapkan secara sempurna. Salah satu sumber belajar yang dapat digunakan agar lebih cepat dan mudah dalam menguasai suatu kompetensi dalam diklat adalah modul.

Menurut Departemen Pendidikan Nasional (2008) Modul didefinisikan sebagai sumber belajar yang didesain agar bisa dipelajari secara mandiri oleh peserta diklat dalam proses pembelajaran dimanapun dan kapanpun. Artinya, peserta diklat bisa melaksanakan proses belajar tanpa kehadiran secara langsung. Modul dirancang sedemikian rupa sesuai dengan kurikulum yang ditetapkan berdasarkan kebutuhan suatu lembaga atau instansi dan ditampilkan dalam satuan sumber belajar terkecil yang dapat dipelajari kapanpun dan dimanapun secara mandiri (Purwanto, et al., 2007). 
Goldschmid dalam Wijaya (1988) mengatakan modul dirancang sedemikian rupa agar membantu peserta didik mencapai tujuan akhir dengan kegiatan belajar terencana. Sukmadinata (2008) mengungkapkan bahwa modul merupakan produk hasil dari kegiatan R\&D dengan tujuan menghasilkan produk baru atau penyempurnaan dari produk yang telah tersedia menjadi lebih baru dan lebih layak digunakan.

Modul merupakan salah satu jenis materi pelatihan yang diolah secara sistematik dan menghasilkan pengalaman pembelajaran unik yang digunakan untuk membantu siswa menguasai tujuan spesifik (Daryono \& Rochmadi, 2020).

Pengembangan modul pembelajaran bertujuan untuk meningkatkan efektivitas dan hasil belajar peserta diklat yang sebelumnya minim menjadi lebih baik (Patkur \& Wibowo, 2013), selain itu juga menciptakan pembelajaran yang efektif, efisien dan fokus pada tujuan pembelajaran (Setiyadi, 2017).

Dalam pengembangan modul ini digunakan metode 4D Thiagarajan (1974) terdiri 4 tingkatan proses pengembangan yaitu Define, Design, Develop, dan Disseminate. Peneliti dalam hal ini tidak dapat melaksanakan hingga Disseminate dikarenakan keterbatasan waktu dari peneliti untuk melakukan evaluasi setelah menyebarkan modul ini. Modul pembelajaran disusun berdasarkan needs analysis, module design development, implementasi, penilaian, evaluasi dan validasi serta penjaminan mutu kualitas (Daryanto, 2013).

Konstruksi jalan atau perkerasan jalan mulai dikenal dari zaman romawi kuno hingga dikenalkan sistem perkerasan jalan sederhana yang tercatat dalam literatur resmi seperti sistem konstruksi jalan McAdam yang dikenalkan oleh John McAdam (Mustajib, 2019). Konstruksi jalan diciptakan untuk memfasilitasi kegiatan angkut barang ataupun manusia yang dilakukan sejak dulu kala (Haryanto \& Utomo, 2012).

Jalan di Indonesia dapat diklasifikasikan berdasarkan peranannya yaitu, jalan arteri untuk angkutan jarak jauh, jalan arteri untuk angkutan jarak dekat menengah dan jalan lokal untuk angkutan setempat (Sutrisno \& Budimanto, 2012). Dari jenis perkerasannya terdapat tiga jenis perkerasan jalan, yaitu perkerasan jalan kaku (rigid pavement), jalan lentur (flexible pavement) dan perkerasan kombinasi (composite pavement) (Mustajib, 2019).

Perkerasan jalan yang sangat dikenal di Indonesia adalah perkerasan jalan menggunakan bahan aspal alam dan aspal buatan (Saodang, 2005). Sementara untuk perkerasan kaku terbuat dari, batu kerikil, pasir, dan semen. Perencanaan merupakan proses menentukan tujuan di masa mendatang dengan menetapkan langkah yang diperlukan (Alder, 1999). Perencanaan perkerasan jalan harus dibentuk berdasarkan data teknis dan data non teknis (Nurman, 2019). Sehingga dapat dikatakan bahwa perencanaan perkerasan jalan adalah proses menentukan tahapan yang perlu dilaksanakan dalam membuat suatu perkerasan jalan.

Dalam perencanaan perkerasan jalan akan mempertimbangkan kebutuhan wilayah penopang, kemampuan tanah menanggung beban layan sehingga dapat menentukan jenis perkerasan yang akan digunakan (Bermawi, et al. 2020). Perencanaan perkerasan jalan yang matang akan sangat mempengaruhi aspek pergerakan ekonomi, mobilitas transportasi manusia dan barang, serta politik (Taswin \& Kadir, 2016).

Fokus pengembangan media diklat berupa modul dengan materi perencanaan perkerasan jalan. Dalam modul diklat ini terdapat tiga pokok bahasan yaitu materi Perencanaan Perkerasan Jalan dan Klasifikasinya, materi Perencanaan Perkerasan Jalan Lentur, serta materi Perencanaan Perkerasan Jalan Kaku. Masing-masing pokok bahasan memiliki konten yang disesuaikan dengan kompleksitas bahasan pada materi perencanaan perkerasan jalan.

Modul yang dirancang disesuaikan dengan kebutuhan perusahaan jasa konstruksi dan panduan manual desain perkerasan jalan (Departemen Pekerjaan Umum, 2013). Dengan adanya modul materi perencanaan perkerasan jalan, diharapkan tujuan pembelajaran dapat tercapai dan materi dapat tersampaikan serta dipahami oleh peserta diklat. Karena pada umumnya kegagalan penyampaian materi kepada 
peserta diklat terjadi karena pembelajaran yang disediakan oleh penyelenggara diklat cenderung membosankan.

Dari penjelasan tersebut disimpulkan bahwa pengembangan media pembelajaran yaitu modul diklat sangat penting karena dapat berguna meningkatkan kemampuan peserta diklat dalam hal ini karyawan di perusahaan jasa konstruksi. Sehingga penelitian ini melakukan pembuatan dan pengembangan modul dengan materi Perencanaan Perkerasan Jalan Raya.

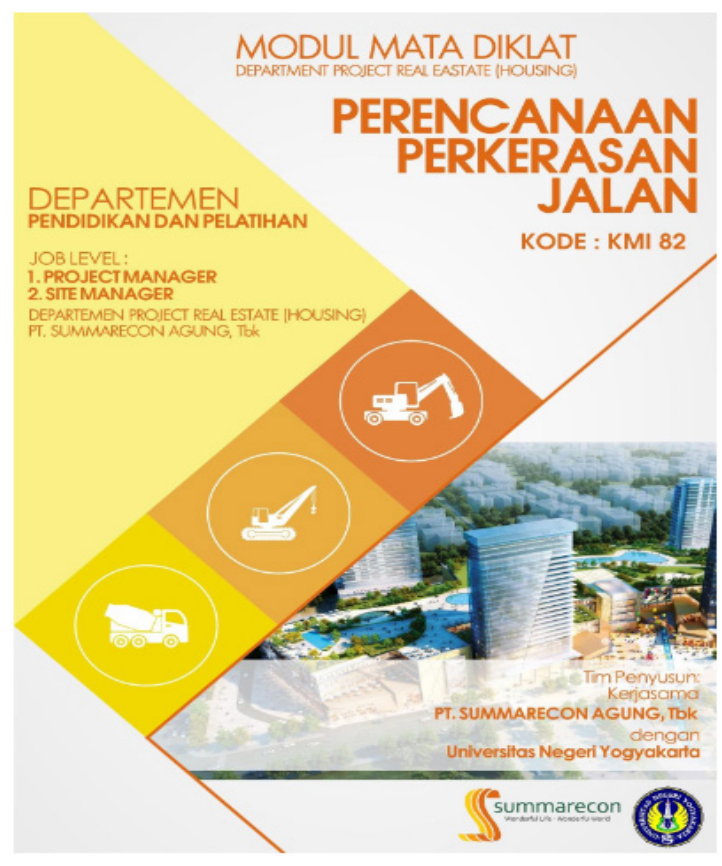

\section{Gambar 1. Cover Modul Perencanaan Perkerasan Jalan}

\section{METODE}

Desain penelitian yang digunakan adalah Research and Development dengan mengadaptasi model 4D-Thiagarajan (Thiagarajan, 1974). Model ini dipilih karena akan memudahkan proses pembuatan modul berbasis kerjasama dua lembaga yang membutuhkan saling keterbukaan dalam pengambilan data, pengolahan data, penentuan data yang akan dipakai menjadi modul dan asesmen yang akan digunakan oleh perusahaan.

Ahli materi dan ahli media pembelajaran Fakultas Teknik UNY merupakan subyek dari studi penelitian ini. Penelitian dan pengembangan media pembelajaran modul dilaksanakan di jurusan Pendidikan Teknik Sipil dan Perencanaan pada Januari 2018 - Mei
2018. Data dikumpulkan melalui pengamatan, pengumpulan dokumen pendukung dan angket penilaian modul.

Data penelitian untuk mengembangkan modul diperoleh dari data sekunder dari perencanaan perkerasan jalan yang sudah dilaksanakan oleh perusahaan dan beberapa data pendukung yang didapatkan dari lapangan. Modul ini dikembangkan dari tahap Define yaitu dari 1) analisis kebutuhan materi modul yang dilakukan dengan observasi lapangan, dokumentasi di perusahaan jasa konstruksi yang terkait; 2) analisis kurikulum dilakukan untuk mengetahui kompetensi apa yang ingin dicapai; 3) mengumpulkan referensi materi dengan melakukan identifikasi silabus diklat dan materi yang dibutuhkan di dalam modul perencanaan perkerasan jalan.

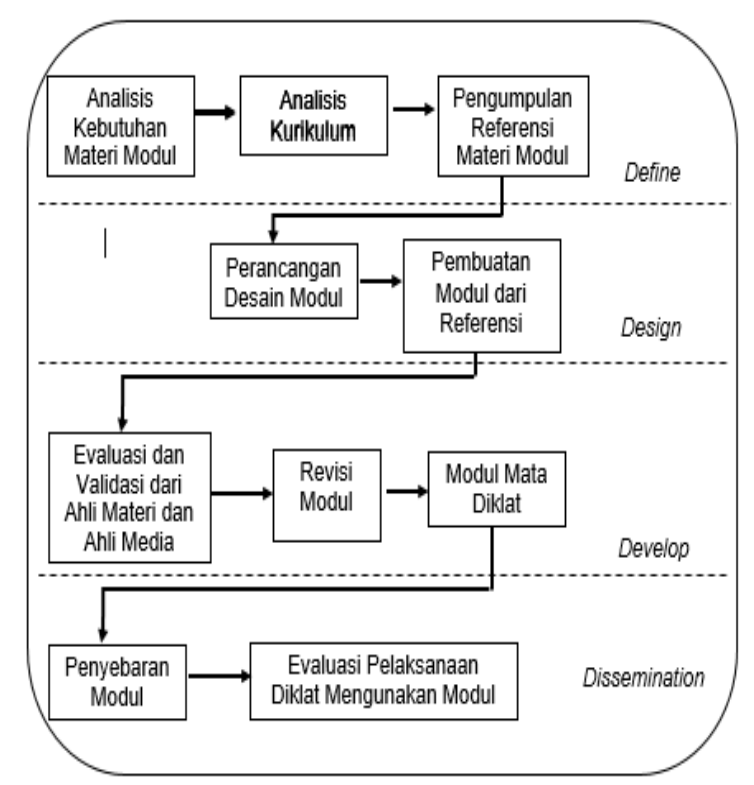

\section{Gambar 2. Tahapan Metode Penelitian 4D}

Selanjutnya dilakukan tahapan Design yaitu merancang modul, dimulai dari cover, halaman balik judul dan perkenalan, halaman kata pengantar, diikutidaftar isi, bagan cakupan materi, materi dan tujuan pembelajaran, materi pembelajaran, rangkuman, tes, kunci jawaban, referensi tambahan, daftar pustaka dan halaman lampiran. Kemudian dilakukan pengembangan isi modul berdasarkan referensi yang telah diperoleh beserta data di lapangan.

Selanjutnya dalam tahapan Develop, 
untuk menguji kelayakan modul sebelum sampai di tangan pengguna, dilakukan penilaian dan uji kevalidan dari ahli materi modul dan ahli media modul, setelah diberi masukan lalu direvisi hingga diperoleh modul yang paling layak digunakan. Dalam tahap Dissemination, penyebaran dilakukan langsung oleh penyelenggara diklat yaitu perusahaan jasa konstruksi. Keterbatasan penelitian ini adalah peneliti hanya sampai pada tahap menyerahkan modul kepada pihak penyelenggara sehingga tidak melakukan evaluasi pelaksanaan diklat menggunakan modul.

Untuk mengetahui seberapa layak modul tersebut digunakan pada diklat perusahaan, maka dari angket penilaian modul yang disebar kemudian diolah dengan teknik analisis statistik deskriptif (Sugiyono, 2016). Menggunakan modifikasi dari skala Likert dan uji signifikansi atau taraf kesalahan pada data yang telah diberikan oleh ahli media pembelajaran dan ahli materi perencanaan perkerasan jalan (Arikunto, 2012).

Kemudian untuk menyajikan datanya menggunakan nilai rerata ideal (Mi), simpangan baku ideal (Sbi), jumlah rerata perolehan skor, skor tertinggi dan skor terendah. Dan rumus untuk nilai rerata ideal (Mi) dan simpangan baku ideal (Sbi) sebagai berikut:

$$
\begin{aligned}
& \mathrm{Mi}=\frac{1}{2} \times(\text { Skor maksimal ideal }- \\
& \text { Skor minimal } \text { ideal }) \\
& \mathrm{Sbi}=\frac{1}{6} \times(\text { Skor } \text { maksimal ideal }- \\
& \text { Skor minimal ideal })
\end{aligned}
$$

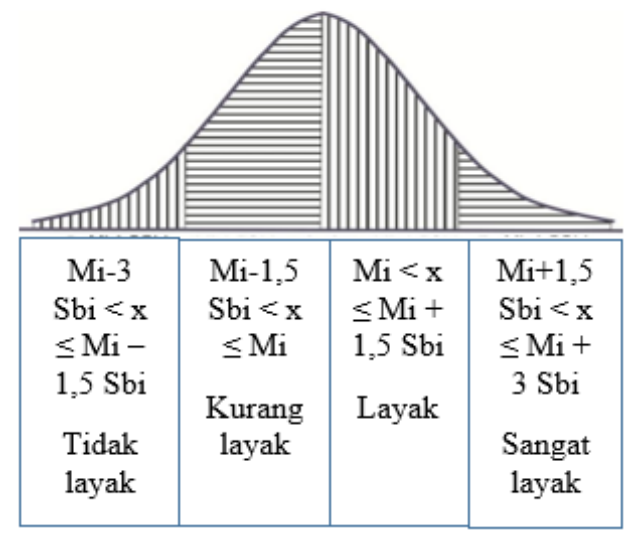

Gambar 3. Grafik Uji Signifikansi Kelayakan Modul

\section{HASIL DAN PEMBAHASAN}

Setelah dilakukan penelitian diperoleh penilaian dari ahli media pembelajaran dan ahli materi perencanaan perkerasan jalan yang dapat digunakan untuk pengembangan modul menjadi lebih baik. Dalam validasi para ahli memberikan penilaian terhadap modul yang telah dibuat, sehingga dapat dinyatakan layak digunakan atau tidak layak digunakan. Dalam validasi diberi rentang nilai 1 hingga 4 yang mempermudah penilaiannya.

Tabel 1. Modifikasi Skala Likert untuk Penilaian

\begin{tabular}{ll}
\hline Skor & Kriteria \\
\hline 1 & Tidak Sesuai \\
2 & Kurang Sesuai \\
3 & Sesuai \\
4 & Sangat Sesuai \\
\hline
\end{tabular}

\section{Validasi Ahli Materi}

Validasi dari ahli materi modul memberikan penilaian terhadap aspek self instruction, self contained, stand alone, dan adaptif. Secara

\begin{tabular}{|c|c|}
\hline Aspek & Indikator \\
\hline \multirow{8}{*}{$\begin{array}{l}\text { Self } \\
\text { Instruction }\end{array}$} & Tujuan pembelajaran yang jelas \\
\hline & $\begin{array}{l}\text { Materials packaging yang menarik } \\
\text { disertai contoh dan ilustrasi }\end{array}$ \\
\hline & $\begin{array}{l}\text { Ketersediaan tugas untuk } \\
\text { mengukur kemampuan peserta } \\
\text { diklat }\end{array}$ \\
\hline & $\begin{array}{l}\text { Materi berkaitan erat dengan } \\
\text { keadaan, tugas dan konteks } \\
\text { aktivitas pekerjaan }\end{array}$ \\
\hline & $\begin{array}{l}\text { Penggunaan bahasa mudah } \\
\text { dimengerti dan komunikatif }\end{array}$ \\
\hline & $\begin{array}{l}\text { Ada rangkuman materi } \\
\text { pembelajaran }\end{array}$ \\
\hline & $\begin{array}{l}\text { Tersedia instrumen penilaian, } \\
\text { umpan balik atas penilaian peserta } \\
\text { didik, serta kunci jawaban yang } \\
\text { terkait materi }\end{array}$ \\
\hline & Tersedia daftar pustaka pendukung \\
\hline
\end{tabular}
rinci, instrumen kelayakan modul dari ahli materi dijelaskan pada tabel 2 .

\section{Tabel 2. Indikator instrumen ahli materi}




\begin{tabular}{|c|c|}
\hline $\begin{array}{l}\text { Self } \\
\text { Contained }\end{array}$ & $\begin{array}{l}\text { Memuat materi pembelajaran } \\
\text { sesuai kompetensi tujuan }\end{array}$ \\
\hline Stand Alone & $\begin{array}{l}\text { Tidak terlalu kaku dan bergantung } \\
\text { pada bahan ajar lainnya }\end{array}$ \\
\hline Adaptif & $\begin{array}{l}\text { Fleksibel dan mudah menyesuaikan } \\
\text { dengan perkembangan iptek terkini } \\
\text { serta mudah diakses pada berbagai } \\
\text { perangkat }\end{array}$ \\
\hline \multirow[t]{2}{*}{$\begin{array}{l}\text { User } \\
\text { Friendly }\end{array}$} & $\begin{array}{l}\text { Instruksi dan informasi mudah } \\
\text { digunakan }\end{array}$ \\
\hline & Bersahabat dengan pemakai \\
\hline
\end{tabular}

Dari hasil penilaian kelayakan dari ahli materi jika dibagi berdasarkan aspeknya akan dijabarkan pada tabel 3.

Tabel 3. Data skor berdasarkan aspek

\begin{tabular}{llll}
\hline Data & Skor & $\begin{array}{l}\text { S k o r } \\
\text { Maks }\end{array}$ & Persentase \\
\hline $\begin{array}{l}\text { Self } \\
\text { Instruction }\end{array}$ & 71 & 84 & 84,52 \\
\hline $\begin{array}{l}\text { Self } \\
\text { Contained }\end{array}$ & 11 & 12 & 91,67 \\
\hline $\begin{array}{l}\text { Stand } \\
\text { Alone }\end{array}$ & 6 & 8 & 75 \\
\hline $\begin{array}{l}\text { Adaptif } \\
\text { User }\end{array}$ & 3 & 4 & 75 \\
Friendly & 10 & 12 & 83,3 \\
\hline
\end{tabular}

Dari hasil penilaian total kelayakan dari ahli materi diperoleh skor seperti ditampilkan pada tabel 4.

\section{Tabel 4. Data skor total ahli materi}

\begin{tabular}{ll}
\hline Data & Skor \\
\hline Skor yang diperoleh & 101 \\
Butir Soal & 30 \\
Skor Maksimal Ideal & 120 \\
Skor Minimal Ideal & 30 \\
Rerata Ideal (Mi) & 75 \\
Simpangan Baku Ideal (Sbi) & 15 \\
\hline
\end{tabular}

Dari data berdasarkan tabel 4 kemudian dimasukkan ke dalam grafik uji signifikansi seperti gambar 5 .

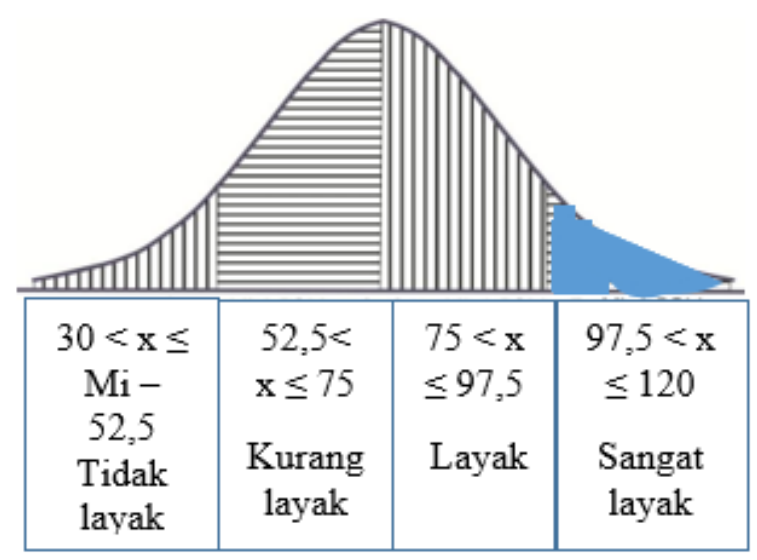

Gambar 5. Grafik Uji Signifikansi Kelayakan Modul menurut Ahli Materi

Berdasarkan skor yang diperoleh sebesar 101, ahli materi menyatakan bahwa modul materi perencanaan perkerasan jalan dikategorikan sangat layak untuk dipakai dalam diklat.

\section{Validasi Ahli Media Pembelajaran}

Validasi dari ahli media pembelajaran modul memberikan penilaian terhadap aspek format, organisasi, attraction atau daya tarik, bentuk dan ukuran huruf yang digunakan, space, serta konsistensi media modul. Secara terperinci, instrumen kelayakan modul dari ahli media dijabarkan pada tabel 5 .

Tabel 5. Indikator instrumen ahli media

\begin{tabular}{ll}
\hline Aspek & Indikator \\
\hline Format & Baris kolom yang sesuai \\
\cline { 2 - 2 } & Ukuran kertas yang memudahkan \\
& dibaca \\
\cline { 2 - 2 } & Keterbacaan teks (huruf cetak, \\
& tebal, miring, cetak tebal, cetak \\
& miring, dan cetak tebal miring) \\
\hline Organisasi & Mind-map materi dalam modul \\
& jelas \\
& Kelengkapan bahan ajar dalam \\
& modul \\
& Sistematika urutan materi modul \\
& perencanaan perkerasan jalan \\
& Penempatan teks naskah, gambar \\
& $\begin{array}{l}\text { dan ilustrasi pendukung serta } \\
\text { formula (rumus) yang sesuai }\end{array}$ \\
& $\begin{array}{l}\text { Susunan alur antar bab, unit, dan } \\
\text { paragraf yang sesuai }\end{array}$ \\
\hline
\end{tabular}




\begin{tabular}{ll}
\hline Daya Tarik & $\begin{array}{l}\text { Kombinasi warna, ilustrasi dan } \\
\text { gambar, bentuk dan ukuran huruf } \\
\text { pada cover modul menarik dan } \\
\text { selaras }\end{array}$ \\
\cline { 2 - 2 } & $\begin{array}{l}\text { Terdapat gambar dan ilustrasi } \\
\text { pada bagian isi modul yang sesuai }\end{array}$ \\
\hline Bentuk dan & Keterbacaan bentuk dan ukuran \\
ukuran huruf & huruf pada cover dan isi modul \\
\hline Ruang (Space) & Spasi antar teks sudah sesuai \\
\hline User Friendly & $\begin{array}{l}\text { Konsistensi bentuk huruf, spasi, } \\
\text { dan tata letak pengetikan tiap } \\
\text { halaman }\end{array}$ \\
\hline
\end{tabular}

Dari hasil penilaian kelayakan dari ahli materi jika dibagi berdasarkan aspeknya akan dijabarkan pada tabel 6 .

Tabel 6. Data skor berdasarkan aspek

\begin{tabular}{llll}
\hline Data & Skor & $\begin{array}{l}\text { S k o r } \\
\text { Maks }\end{array}$ \\
\hline Format & 19 & 20 & 95 \\
\hline Organisasi & 31 & 32 & 96,875 \\
\hline Daya Tarik & 16 & 16 & 100 \\
\hline $\begin{array}{l}\text { Bentuk dan } \\
\text { Ukuran } \\
\text { Huruf }\end{array}$ & 16 & 16 & 100 \\
\hline $\begin{array}{l}\text { Ruang } \\
\text { (Space) }\end{array}$ & 11 & 12 & 91,67 \\
\hline $\begin{array}{l}\text { User } \\
\text { Friendly }\end{array}$ & 24 & 24 & 100 \\
\hline
\end{tabular}

Data skor total yang diperoleh berdasarkan penilaian kelayakan ahli media pembelajaran disajikan di tabel 7 .

Tabel 7. Data skor total ahli media

\begin{tabular}{ll}
\hline Data & Skor \\
\hline Skor yang diperoleh & 117 \\
Butir Soal & 30 \\
Skor Maksimal Ideal & 120 \\
Skor Minimal Ideal & 30 \\
Rerata Ideal (Mi) & 75 \\
Simpangan Baku Ideal (Sbi) & 15 \\
\hline
\end{tabular}

Dari data yang diperoleh dari tabel 7 kemudian dimasukkan ke dalam grafik uji signifikansi seperti gambar 6 .

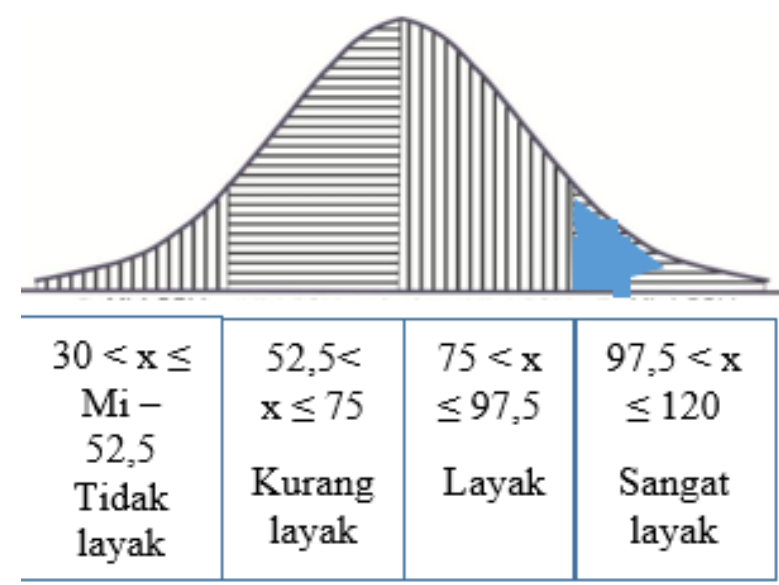

\section{Gambar 6. Grafik Uji Signifikansi Kelayakan Modul menurut Ahli Media Pembelajaran}

Berdasarkan skor yang diperoleh sebesar 117, ahli media pembelajaran menyatakan bahwa modul materi perencanaan perkerasan jalan masuk dalam kategori sangat layak digunakan dalam diklat.

\section{Pembahasan}

Pengembangan media pembelajaran berupa modul sangat membantu peserta diklat dalam mencapai tujuan pembelajaran serta hasil akhir yang sesuai harapan, modul yang baik harus mudah dipahami oleh kalangan yang akan mengikuti diklat dalam hal ini adalah karyawan perusahaan jasa konstruksi di bidang infrastruktur jalan dan yang menjadi penguji kevalidan dan kelayakan modul adalah ahli materi perencanaan perkerasan jalan dan ahli media modul pembelajaran. Pengembangan materi modul pembelajaran harus efektif dan tepat sasaran sesuai kompetensi yang akan diperoleh peserta diklat, tidak membuang waktu dan mubazir ilmu yang mungkin tidak diperlukan kompetensi itu namun tetap dimasukkan dalam materi modul (Enke, et al., 2015)

Beberapa penelitian sebelumnya mengungkapkan bahwa modul yang layak dipakai harus mendapat rekomendasi dari ahli materi dan ahli media pembelajaran terlebih dahulu sebelum disebarluaskan di kalangan tertentu (Akbar, 2017; Marleni \& Widarwati, 2017). Selain itu dalam penggunaan modul juga ditemukan bahwa pembelajaran dengan modul berhasil meningkatkan nilai positif dan prestasi belajar siswa secara signifikan 
dibanding tanpa media pembelajaran (Sasmayaputra, 2015; Setiawati, 2016).

Penelitian Zuki dan Hamzah (2014) dalam pengembangan modul berbasis integrated holistic teaching guide untuk peserta pelatihan para calon guru Technical and Vocational Education (TVE) menunjukkan hasil berupa penilaian positif dari tiga ahli yang menyatakan bahwa modul tersebut dalam kategori terverifikasi sangat layak dan mampu meningkatkan kualitas diri calon guru TVE. Dalam penelitian lainnya, Firdaus, et al. (2019) mengembangkan modul untuk pembelajaran pengelasan menggunakan SMAW yang menunjukkan peningkatan kompetensi dan prestasi belajar yang diperoleh siswa dan ada penilaian positif dari aspek tampilan, penyajian materi dan manfaat modul yang dikembangkan.

Dalam penelitian Risnawati, et al. (2019) yang bertujuan untuk meningkatkan keterampilan penalaran peserta didik/peserta diklat, dalam hal ini penelitiannya mendapat penilaian akhir dengan kriteria layak, praktis dan efektif digunakan, lalu penelitian lainnya yang dilakukan Wicaksana, et al. (2020) bertujuan mengetahui keefektifan aspek berpikir kritis melalui modul untuk meningkatkan prestasi akademik siswa, hasilnya modul tersebut berdampak baik terhadap prestasi belajar siswa yang meningkat.

Keefektifan pembelajaran dengan modul jika diaplikasikan pada proses pembelajaran dibandingkan cara tradisional yang terkesan membosan karena berpusat pada teacher centered seperti metode ceramah (Muhlisin, 2012; Nurcahyani, 2016). Perubahan prestasi belajar peserta diklat ataupun siswa menggunakan modul dibuktikan oleh penelitian yang dilakukan oleh Siahaan (2017) yang menemukan perbedaan prestasi belajar antara siswa SMK yang menggunakan modul pembelajaran AutoCad menjadi lebih tinggi dibanding dengan yang tidak menggunakan modul pembelajaran AutoCad.

Daryono \& Rochmadi (2020) melakukan pengujian kelayakan ahli materi dan media dalam pengembangan modul pembelajaran pemeliharaan gedung untuk siswa SMK memperoleh penilaian sangat layak digunakan karena juga bermanfaat pada pelaksanaan pembelajaran di SMK tersebut dan disambut baik oleh guru dan siswa yang menggunakannya. Hasil penelitian-penelitian tersebut mendukung hasil penelitian yang saya lakukan bahwa dalam diklat sangat diperlukan media pembelajaran yang akan mempermudah peserta diklat dalam memahami dan meningkatkan prestasi belajar sehingga tujuan pembelajaran dapat tercapai dengan tepat. Hal yang sama juga ditemui pada penelitian Mithafudin \& Supriyanto (2015) serta Setiyadi (2017) yang mengembangkan modul dengan metode 4D dan mampu membuat pembelajaran terlaksana dengan baik dan diterima secara positif oleh guru dan siswa serta dinilai mampu meningkatkan kemampuan siswa tempat dimana uji terbatas dilaksanakan.

Bagi para instruktur diklat dapat terbantu dengan adanya modul yang lebih efektif dibandingkan pembelajaran konvensional yang sangat sulit dipahami peserta diklat. Selain itu modul juga harus melewati proses validasi oleh ahli materi perencanaan perkerasan jalan dan ahli media pembelajaran sehingga modul yang dirancang sesuai kebutuhan pendidikan dan pelatihan karyawan di perusahaan tersebut. Setelah dinilai layak disebar, barulah dapat disebarluaskan di program diklat perusahaan tersebut. Tahap diseminasi dilakukan dengan pendistribusian buku modul ke perusahaan terkait dan melalui google drive untuk memudahkan penyebaran data.

\section{SIMPULAN}

Hasil dari validasi kelayakan yang dilakukan oleh ahli media pembelajaran bahwa modul yang dikembangkan sudah memenuhi kaidah media yang menarik, layak, mudah diakses, dipahami dan digunakan oleh peserta diklat perencanaan perkerasan jalan. Sementara menurut ahli materi mengungkapkan bahwa modul perencanaan perkerasan jalan yang dikembangkan sangat layak untuk digunakan peserta diklat bidang infrastruktur perkerasan jalan, materi yang diberikan dalam modul sudah mencakup kompetensi yang dibutuhkan peserta diklat di tingkatan pelaksana pekerjaan jalan ataupun 
pengawas setingkat manajer yang bertugas mengawasi pekerjaan jalan.

Proses penyempurnaan modul harus terus dilakukan agar mengikuti perkembangan di dunia teknik sipil terutama di bidang infrastruktur jalan sehingga peserta diklat dapat terus memperluas pengetahuannya serta meningkatkan kemampuannya di bidang infrastruktur dan dapat saling memberikan simbiosis mutualisme antara perusahaan dengan karyawannya.

Selain itu penelitian Munadi \& Sunarto (2013) yang menemukan beberapa kendala dari para peserta yang menggunakan modul terutama yang berbasis elektronik adalah kesiapan dari tenaga pengajar, peserta, peralatan pendukung media menggunakan komputer, dan literasi komputer yang tidak sama rata juga harus diperhatikan, walaupun secara umum masih dapat digunakan banyak kalangan. Sehingga ini menjadi perhatian peneliti ataupun pengembang media pembelajaran modul untuk menyediakan hardcopy dan softcopy dari modul tersebut agar mengikuti kebutuhan dari pengguna modul.

\section{REFERENSI}

Akbar, A.B. (2017). Pengembangan Modul Mata Pelajaran Gambar Teknik untuk Siswa Kelas X Program Keahlian Teknik Gambar Bangunan di SMK 1 Sedayu. Skripsi. Fakultas Teknik Universitas Negeri Yogyakarta.

Alder. (1999). Coastal Planning and Management. New York: E \& FN SPON

Bermawi, Y., Latif, A., \& Absor, M. (2020). Pelatihan Pelaksanaan Pekerjaan Perkerasan Jalan Bagi Masyarakat Konstruksi. SNAPTEKMAS, 1(1).

Daryanto. (2013) Menyusun Modul (Bahan Ajar untuk Persiapan Guru dalam Mengajar). Yogyakarta: Gava Media.

Daryanto \& Bintoro. (2014). Manajemen Diklat. Yogyakarta: Gava Media.

Daryono, R., \& Rochmadi, S. (2020). Development of learning module to improve competency achievement in the department of civil engineering education in Indonesia. Psychology, Evaluation, and Technology in
Educational Research, 3(1). Doi:http:// dx.doi.org/10.33292/petier.v3il.54

Departemen Pekerjaan Umum. (2013). Manual Desain Perkerasan Jalan 2013 (Nomor 02/M/BM/2013). Jakarta: Departemen Pekerjaan Umum Direktoral Jendral Bina Marga.

Departemen Pendidikan Nasional. (2008). Pengembangan Bahan Ajar dan Media. Jakarta: Departemen Pendidikan Nasional.

Enke, J., Kraft, K., \& Metternich, J. (2015). Competency-oriented design of learning modules. Procedia CIRP, 32(2015), 7-12.

Firdaus, H., Jalinus, N., \& Effendi, H. (2019). Development of learning Modules Manual Shield Metal Arc Welding (SMAW) with service learning approach. International Research Journal of Advanced Engineering and Science, 2(2), 247-251.

Kementerian Ketenagakerjaan. (2003). Undang-Undang Republik Indonesia Nomor 13 Tahun 2003 tentang Ketenagakerjaan. Jakarta: Kementerian Ketenagakerjaan.

Kementerian Tenaga Kerja dan Transmigrasi. (2014). Peraturan Menteri Tenaga Kerja dan Transmigrasi RI Pasal 7 Nomor 8 Tahun 2014 tentang Pedoman Penyelenggaraan Pelatihan Berbasis Kompetensi.

Kementerian Ketenagakerjaan. (2016). Peraturan Meneteri Ketenagakerjaan RI Nomor 2 Tahun 2016 tentang Sistem Standarisasi Kompetensi Kerja Nasional. Kementerian Pendidikan dan Kebudayaan. (2012). Undang-Undang Republik Indonesia Nomor 12 Tahun 2012 tentang Pendidikan Tinggi. Jakarta: Kementerian Pendidikan dan Kebudayaan.

Haryanto, I. \& Utomo, H.B. (2012). Bahan Ajar Perkerasan Jalan: Pengembangan Pembelajaran Berbasis Riset dan Education for Sustainable Development untuk Mata Kuliah Perkerasan Jalan Raya dengan Memanfaatkan Hasil Riset Terapan Ecomaterial. Yogyakarta: Pengembangan Pendidikan Universitas Gadjah Mada.

Marleni, E. \& Widarwati, S. (2017). 
Pengembangan Video Pembelajaran Pewarnaan Teknik Kering Mata Pelajaran Desain Busana di SMK N 6 Yogyakarta. E-Journal Pendidikan Teknik Busana-S1, 6(5).

Miftahudin, N., \& Suprianto, B. (2015). Pengembangan Modul Trainer Parkir Mobil Sistem Informatif sebagai Media Pembelajaran pada Mata Diklat PLC Kelas XI Teknik Otomasi Industri SMK Negeri 3 Boyolangu-Tulungagung. Jurnal Pendidikan Teknik Elektro, 4(3).

Munadi, S., \& Sunarto, S. (2013). Pengembangan Modul Pembelajaran Konstruktivistik Kontekstual Berbantuan Komputer Dalam Mata Diklat Pemesinan. Artikel Ilmiah Tugas Akhir. Fakultas Teknik Universitas Negeri Yogyakarta.

Muhlisin, A. (2012). Pengembangan Media Modul pada Mata Pelajaran Menggunakan Mesin untuk Operasi Dasar Kelas X SMK Muhammadiyah 3 Yogyakarta. Skripsi. Fakultas Teknik Universitas Negeri Yogyakarta.

Mustajib, M. C. (2019). Pembuatan Media Pembelajaran Aplikasi Berbasis Android Pada Mata Pelajaran Teknik Pelaksanaan Dan Pengawasan Pekerjaan Jalan (Tp3jl) Kd1-Kd4 Kelas XI Di SMK Negeri 7 Semarang. Skripsi. Fakultas Teknik Universitas Negeri Semarang.

Nawawi, A. (2016). Pengembangan Sumber Daya Manusia Melalui OJT. Jurnal Manajemen Pusdiklat Migas, Vol. 06 No. 2. Diakses pada 15 Juli 2020.

Nurcahayani, W. (2016). Pengembangan Bahan Ajar Berupa Modul Sejarah Indonesia pada Materi Tantangan Awal Indonesia Merdeka Terhadap Hasil Belajar Siswa Kelas XI SMA Negeri 1 Gubug Tahun Ajaran 2014/2015. Skripsi. Fakultas Teknik Universitas Negeri Yogyakarta.

Nurman, L. (2019). Evaluasi Tebal Perkerasan Kaku dengan Metode Bina Marga Mdp Pd T-14-2013 Studi Kasus Jalan Sungai Jering-Kari. Teluk Kuantan. Jurnal Perencanaan, Sains, Teknologi, dan Komputer, 2(1), 286-295.

Patkur, M., \& Wibowo, T. W. (2013). Pengembangan Modul Pembelajaran
AutoCad untuk Meningkatkan Efektivitas Pembelajaran Siswa Kelas $X$ TPM di SMKN 1 Sidoarjo. Jurnal Pendidikan Teknik Mesin, 1(03), 86-96.

Purwanto, Rahadi, A., \& Lasmono, S. (2007). Pengembangan Modul. Jakarta: Pusat Teknologi Informasi dan Komunikasi Pendidikan (PUSTEKKOM) Depdiknas.

Risnawati, R., Andrian, D., Azmi, M. P., \& Nurdin, E. (2019). Development of a definition map-based plane geometry module to improve the student teachers' mathematical reasoning ability. International Journal of Instruction, 12(3), 541-560. https://doi. org/10.29333/iji.2019.12333a

Sadiman, et al. (2011). Media Pendidikan, Pengertian, Pengembangan dan Pemanfaatannya. Jakarta: PT. Raja Grafindo Perkasa.

Saodang, Hamirhan. (2005). Pengertian Jalan Perkeasan Kaku. Bandung: Nova

Sasmayaputra, N.A. (2015). Pengembangan Media Modul Pembelajaran Konstruksi Bangunan untuk Pembelajaran Konstruksi Bangunan di SMKN 1 Sedayu Bantul. Skripsi. Fakultas Teknik Universitas Negeri Yogyakarta.

Setiawati, E. (2016). Pengembangan Media Pembelajaran Modul pada Materi Animalia Kelas X SMAN 1 Pontianak. Skripsi. Fakultas Keguruan dan IImu Pendidikan Universitas Muhammadiyah Pontianak.

Setiyadi, M. W. (2017). Pengembangan modul pembelajaran biologi berbasis pendekatan saintifik untuk meningkatkan hasil belajar siswa. Journal of Educational Science and Technology (EST), 3(2), 102-112.

Siahaan, A. (2017). Pengembangan Modul Pembelajaran Pada Kompetensi AutoCad Siswa SMK. Jurnal teknologi Informasi \& Komunikasi Dalam Pendidikan, 4(1).

Sugiyono. (2016). Metode Penelitian Pendidikan: Pendekatan Kuantitatif, Kualitatif dan R\&D. Bandung: Alfabeta.

Sukmadinata, N. S. (2008). Metode Penelitian dalam Pendidikan.

Sutriono, B., \& Budimanto, E. (2012). Analisis 
Ketebalan Dan Biaya Perkerasan Jalan Di Ruas Jalan Raya Lamongan-Mojokerto. Extrapolasi: Jurnal Teknik Sipil, 5(01).

Taswin, M., \& Kadir, A. A. (2016). Perencanaan Pembangunan Jalan Griya Abdi Negara Kota Pagar Alam. Jurnal Ilmiah Bering's, 3(02), 56-61.

Thiagarajan. (1974). Instructional Development for Training Teachers of Exceptional Children. Minneapolis: Indiana University.

Wicaksana, Y.D., Widoretno, S., \& Dwiastuti, S. (2020). The use of critical thingking aspects on module to enhance students' academic achievement. Iternational Journal of Instruction, 13(2), 303314. https://doi.org/10.29333/ iji.2020.13221a

Wijaya, C. (1988). Upaya Pembaharuan dalam Pendidikan dan Pengajaran. Bandung: Remadja Karya.

Zuki, R. E. A., \& Hamzah, R. (2014). Development of integrated holistic teaching guide module for technical and vocational education teacher trainees. Development, 5(8). 